Bond University

Research Repository

\title{
Pleistocene human footprints from the Willandra Lakes, southeastern Australia
}

Webb, S; Cupper, ML; Robins, R

Published in:

Journal of Human Evolution

DOI:

10.1016/j.jhevol.2005.10.002

Licence:

CC BY-NC-ND

Link to output in Bond University research repository.

Recommended citation(APA):

Webb, S., Cupper, ML., \& Robins, R. (2006). Pleistocene human footprints from the Willandra Lakes,

southeastern Australia. Journal of Human Evolution, 50(4), 405-413. https://doi.org/10.1016/j.jhevol.2005.10.002

\footnotetext{
General rights

Copyright and moral rights for the publications made accessible in the public portal are retained by the authors and/or other copyright owners and it is a condition of accessing publications that users recognise and abide by the legal requirements associated with these rights.
}

For more information, or if you believe that this document breaches copyright, please contact the Bond University research repository coordinator. 


\section{Bond University}

\section{ePublications@bond}

$1-1-2006$

\section{Pleistocene human footprints from the Willandra Lakes, southeastern Australia}

Steve Webb

Bond University,Steve_Webb@bond.edu.au

Matthew L. Cupper

University of Melbourne, cupper@unimelb.edu.au

Richard Robins

University of New England, N.S.W.

Follow this and additional works at: http://epublications.bond.edu.au/hss_pubs

Part of the Archaeological Anthropology Commons

\section{Recommended Citation}

Steve Webb, Matthew L. Cupper, and Richard Robins. (2006) "Pleistocene human footprints from the Willandra Lakes, southeastern Australia" ,, .

http://epublications.bond.edu.au/hss_pubs/40 


\title{
Pleistocene human footprints from the Willandra Lakes, southeastern Australia
}

\author{
By Steve Webb ${ }^{\mathrm{a}^{*}}$ Matthew L. Cupper ${ }^{\mathrm{b}}$, Richard Robins ${ }^{\mathrm{c}}$ \\ *Corresponding author. stwebb@staff.bond.edu.au (S. Webb), \\ ${ }^{a}$ Faculty of Humanities and Social Sciences, Bond University, Robina, Queensland \\ 4229, Australia. ' School of Earth Sciences, The University of Melbourne, Victoria 3010, \\ Australia. cupper@unimelb.edu.au 'School of Human and Environmental Studies, \\ University of New England, Armidale, New South Wales 2351, Australia. \\ rerobins@bigpond.net.au
}

Running title: Human footprints from the Willandra Lakes

Keywords: Footprints; Last glacial maximum; Murray Basin; Optically stimulated luminescence dating; Willandra Lakes

\begin{abstract}
Human and other hominid fossil footprints provide rare but important insights into anatomy and behaviour. Here we report recently discovered fossil trackways of human footprints from the Willandra Lakes region of western New South Wales, Australia. Optically dated to between 19-23 ka and consisting of at least 124 prints, the trackways form the largest collection of Pleistocene human footprints in the world. The prints were made by adults, adolescents, and children traversing the moist surface of an ephemeral soak. This site offers a unique glimpse of humans living in the arid inland of Australia at the height of the last glacial period.
\end{abstract}

\section{Introduction}

Pleistocene and earlier hominid foot impressions have been described previously from Africa (Deacon, 1966; Mountain, 1966; Leakey and Hay, 1979; Behrensmeyer and Laporte, 1981; Hay and Leakey, 1982; Roberts and Berger, 1997) and Eurasia (Facorellis et al., 2001; Zhang and Li, 2002; Mietto et al., 2003). Such prints are pivotal to current understanding of locomotor biomechanics in hominids, particularly with respect to the evolution of bipedality (Day and Wickens, 1980; Charteris et al., 1981; Mietto et al., 2003). They also preserve a record of hominid ecology, including subsistence patterns and social behavior. Despite the long occupation of Australia by humans (Roberts et al., 1990, 1994; Turney et al., 2001), no Pleistocene footprints have previously been identified from the continent. The fossil trackways we describe were discovered in the Willandra Lakes region of western New South Wales during 2003 and are the largest known collection of Pleistocene human footprints in the world

TheWillandra Lakes system lies within the Murray Basin of southeastern Australia. It comprises 19 interconnected relict lake basins, which vary in surface area from 6 to 350 km2 (Fig. 1). These basins were filled by runoff from the Eastern Australian Highlands during the last glacial period, finally drying by ca. $18 \mathrm{ka}$ (Bowler, 1998). Lunette dunes on the lake margins provide a record of this environmental change and preserve 
evidence of a human presence dating back at least 46,000 years (Webb, 1989; Bowler, 1998; Bowler et al., 2003). The oldest Australian human remains, Willandra Lakes Hominid 3, come from Lake Mungo, which has also provided the earliest human mitochondrial DNA in the world (Adcock et al., 2001; cf. Cooper et al., 2001). The region is Australia's foremost for the study of late Pleistocene human biology and archaeology.

\section{Site Description And Chronology}

\section{Geomorphic setting}

The footprints cover an area of approximately $700 \mathrm{~m} 2$ on an exposed indurated horizon, or hardpan, near the stranded shoreline of a small, relict lake basin between Lakes Garnpung and Leaghur (Fig. 2a). The hardpan lies within the swale of low sand dunes, part of an undulating terrain of lunettes and abandoned lakebeds formed during previous high water levels in the Willandra Lakes.

The hardpan unit is approximately $150 \mathrm{~mm}$ thick and composed of at least ten superimposed laminae of gypseous silty clay (Fig. 2b). These sediments have been consolidated by fine-grained interstitial gypsum. The hardpan blankets a $0.9 \mathrm{~m}$ thick underlying unit of aeolian clayey sand to fine sand and has a gently dipping, concave (saucer-shaped) morphology (Fig. 3). Its upper surface shows polygonal cracking, with similar surface textures on internal laminae where they are exposed on the eroded margins of the hardpan. Up to $6 \mathrm{~m}$ of aeolian clayey sand and sand overlie the sequence. Much of this overlying sediment has recently been deflated by wind erosion, reexposing parts of the hardpan. The sequence was probably more extensive to the northwest but has been eroded by gullying and deflation.

\section{Footprints and trackways}

At least 123 human footprints and two kangaroo hind paw prints are preserved on the upper surface of the hardpan, with one human footprint on a small exposure of the thirdhighest lamination (Fig. 4a,b). Erosion had exposed 89 of the human footprints when the site was originally discovered and we excavated another 35 from beneath the overlying sediments. Three footprints of a series of 14 within a single trackway extended under adjoining dune sands to the east of the hardpan, suggesting that more footprints are likely to occur at the site (Fig. 4c).

Maximum footprint lengths and breadths are presented in Table 1. Such prints in finegrained sediment provide greater accuracy of foot measurement than those in coarser, sandy sediments, where rim definition is often poorly preserved. However, shallower prints at the site may underestimate foot lengths because such impressions only record heel and hallux lift off, not the distance between the pternion (end of the heel) and the acropodion (point of the longest toe).

Most of the footprints were quite deeply impressed into the hardpan sediments, recording detailed features of foot morphology. Many have separate toe prints, and some preserve impressions of interphalangeal joint, heel and ball, and medial arch structures. Seventy-six of the footprints are contained within eight trackways, with the remaining 48 prints seemingly randomly distributed. Footprint orientation indicates that 
people were moving in all directions across the site, although $65 \%$ of the prints are heading towards the northeast quadrant, with over three-quarters of prints pointing east $\left(0-180^{\circ}\right)$ (Fig. 5).

The eight trackways (T1-8) comprise 4-15 prints (Table 2; Fig. 4a). They contain the most detailed imprints, particularly in T1-4, T7, and T8. Trackways 1-4 are comparatively straight, between 1.3 and $3.9 \mathrm{~m}$ apart, and are the longest, measuring $15.3,15.3,13.8$, and $19.5 \mathrm{~m}$, respectively. Trackway 5 has four prints, with five prints over a distance of $2.6 \mathrm{~m}$ in T6. The seventh track, containing six prints, is $3.6 \mathrm{~m}$ long, and $\mathrm{T} 8$ consists of seven prints over $11 \mathrm{~m}$.

There are many indistinct marks on the exposed surfaces that may be partial prints, indications of other activity, or marsupial or bird tracks. A group of unusual circular or oval impressions was recorded, the most prominent being a cluster of 20 on the secondhighest lamination (Fig. 4d). Diameters of these circular indentations are between 42 and $55 \mathrm{~mm}$. There is also a series of 1.2-4.5 m long linear impressions on the upper surface (Fig. 4a). These shallow grooves are around 43-52 $\mathrm{mm}$ wide and are suggestive of poles or similar objects being dragged across the surface. None appear to be directly related to sets of prints, although these lines are overprinted with footprints in places.

\section{Age of the footprints}

Optically stimulated luminescence (OSL) dating (Huntley et al., 1985; Aitken, 1998) of the burial ages of quartz sand grains from sediments above and below the hardpan was used to constrain the minimum and maximum age for the footprints. Three OSL samples were collected by hammering stainless steel tubes into freshly cleaned vertical sediment faces of excavated sections (Fig. 3). Sample GP02 came from a shallow trench (section 01) in the covering dune, $30 \mathrm{~m}$ from the eastern margin of the exposure and 0.4 $\mathrm{m}$ above the hardpan. A similar trench (section 02) along the western margin of the site exposed the underlying sands, with sample GP03 collected at a depth of $0.5 \mathrm{~m}$ beneath the hardpan.

Sample GP04 was obtained from the thin clayey sand sheet that overlies at least three footprints (section 03; Fig. 4c). The $90-125 \mu \mathrm{m}$ quartz fraction was prepared for dating using standard procedures (Galbraith et al., 1999). Equivalent doses $\left(D_{e}\right)$ were calculated using a single-aliquot regenerative- dose (SAR) protocol with small aliquots of 5-10 grains (Murray and Roberts, 1997; Murray and Wintle, 2000). The protocol, statistical analyses, and analytical apparatus were as described by Stone and Cupper (2003). The single aliquot $D_{e}$ distributions showed no evidence of partial bleaching. Weighted mean $D_{e}$ and their uncertainties were therefore calculated using a central age model (Table 3) (Galbraith et al., 1999).

Concentrations of $\mathrm{K}, \mathrm{U}$, and $\mathrm{Th}$ were measured by instrumental neutron activation analysis (INAA) and converted to beta dose rates (Adamiec and Aitken, 1998) with a beta attenuation factor of $0.93 \pm 0.03$ (Mejdahl, 1979). Gamma dose rates were measured in the field using a portable spectrometer for GP02 and GP03. The gamma dose rate for GP04 was derived from the INAA values with an uncertainty of $20 \%$. Internal alpha dose rates were assumed to be $0.03 \pm 0.01 \mathrm{~Gy} \mathrm{ka}^{-1}$ based on previous measurements of quartz from the Willandra Lakes (e.g., Thorne et al., 1999; Bowler et al., 2003). Present day field moisture contents of the sediments were considered broadly 
representative of long-term averages and used to correct attenuation of beta and gamma rays by water (Aitken, 1998).

Cosmic-ray dose rates were determined from established equations (Prescott and Hutton, 1994). The depth of the sample underlying the hardpan (GP03) was timeaveraged to allow for near-surface exposure prior to burial by the blanketing dune. Recent erosion of $0.5,1.5$, and $1.5 \mathrm{~m}$ of sediment was estimated to have occurred from above GP02, GP03, and GP04, respectively. These estimates were based on the assumption that the hardpan has only been re-exposed for a short period of time, which would seem valid given the generally excellent preservation of the footprints.

The dose rate data, $D_{e}$ estimates, and optical ages for the OSL samples are presented in Table 3. The optical ages range from 19 to $23 \mathrm{ka}$ and are in stratigraphic order (Fig. $3 \mathrm{~b}, \mathrm{c})$. An age of $23.0 \pm 1.2 \mathrm{ka}$ (GP03) from sands underlying the hardpan is a maximum bound for the overlying sequence. Ages of $19.4 \pm 1.1$ (GP02) and 19.2 $\pm 1.9 \mathrm{ka}$ (GP04) from the overlying aeolian dune sands are an upper constraint for the footprints. These results indicate a maximum interval of about 4,000 years during which the paleosurface was originally exposed and traversable by people.

\section{Interpretation}

\section{Paleoenvironment of the footprint site}

The thin, gypseous, silty-clay laminae of the hardpan probably accumulated from aeolian sediment that deflated from the floor of the nearby lake basin during arid phases. This material was blown onto the site and draped over the underlying dune. Approximately $1 \mathrm{~km}$ inland of the northwestern shore of Lake Garnpung, the hydrology of the small lake adjacent to the footprint site is likely to have become increasingly dominated by evaporitic processes as water levels in the Willandra Lakes waned towards the end of the last glacial maximum (LGM). Gypsum salts and pelletal silty clays typically characterize shoreline sedimentation under such drying conditions (Bowler, 1986).

The ability of humans and marsupials to make foot and paw impressions into its surface shows that the hardpan was at least intermittently moist. Its concave shape and clayey substrate may have pooled surface water for brief intervals after rain. Mottled iron sesquioxide accumulations in underlying dune sands are indicative of locally high and fluctuating groundwater, with seepage from the nearby lake possibly contributing to the formation of a perched water table.

The full sequence of superimposed laminae shows that the hardpan unit accumulated over repeated cycles of wetting and drying of the site. The polygonal texture of their upper surfaces is consistent with desiccation of exposed muddy sediments. Gypsum cemented the drying mud, preserving its sedimentary structures. A final layer of gypseous silty clay was deposited across the site, infilling and sealing the footprints before thick deposits of aeolian silty clays and sands rapidly buried the hardpan.

The timing of the footprints corresponds to the LGM, a period of pronounced climatic variation in southeastern Australia that was coincident with fluctuating lake levels in the Willandra Lakes region (Bowler, 1998; Hesse et al., 2004). This timing accords with the 
soak being ephemerally inundated by surface water between cycles of aeolian deposition and periodic desiccation. Deposition of the blanketing dune is consistent with widespread landscape instability in inland Australia at this time (e.g., Bowler et al., 2003; Hesse et al., 2004; Cupper, 2005).

\section{Paleoanthropology}

The variety of print sizes indicates that people of different ages were present at the site. Assuming a $\pm 10 \mathrm{~mm}$ imprecision due to foot slippage or partial impressions, the range of footprint lengths suggests that a minimum of eight individuals left the prints on the hardpan (Fig. 6). From comparisons with foot length measurements of a modern sample of 478 central Australian Aborigines (Campbell et al., 1936), some of the longer prints were almost certainly made by adult men. Children and adolescents are also clearly represented (Fig. 6).

The people at the footprint site were of a range of statures. The relationship between foot length and height are not known for late Pleistocene peoples, but foot to stature correlations have been found to be almost universal among modern humans (e.g., Topinard, 1878; Hrdlicka, 1935; Robbins, 1986; Giles and Vallandigham, 1991; Barker and Scheuer, 1998; Wunderlich and Cavanagh, 2001; Fessler et al., 2005). This assumption was used to estimate the heights of the individuals (Table 1).

We calculated a conversion factor for extrapolating stature from foot length using anthropometric data sets of Campbell et al. (1936) for 162 male and female central Australian Aborigines aged 26-45 years. Mean stature was divided by mean foot length for each sex, ${ }^{1}$ with $1 \sigma$ precision estimates propagated in quadrature. We used the mean of the male and female values to generate the relationship: height $=$ foot length $\times 6.585$ \pm 0.495 , which equates to foot length averaging $15.19 \pm 1.14 \%$ of height. The mean value for both sexes is likely to overestimate the stature of adult males by less than $2 \%$ $(<40 \mathrm{~mm})$ and underestimate the stature of adult females by a smaller amount.

Footprint length in T1-4 is between $270 \mathrm{~mm}$ and $300 \mathrm{~mm}$, indicating tall-to-very-tall people, almost certainly men. Heights range from $1.78 \pm 0.13 \mathrm{~m}$ in T2 and T4 to $1.88 \pm$ $0.14 \mathrm{~m}$ in $\mathrm{T} 3$ and $1.98 \pm 0.15 \mathrm{~m}(\sim 6.5 \mathrm{ft})$ in $\mathrm{T} 1$, the tallest individual at the site (Table 2). The 48 individual prints scattered across the site have lengths of between $130 \mathrm{~mm}$ and $285 \mathrm{~mm}$. Estimated heights for these people are around $0.86-1.98 \mathrm{~m}$, suggesting a range of individuals from children and adolescents to adults (Table 1; Fig. 6).

\footnotetext{
${ }^{1}$ Such relationships should correctly be based on the foot length to stature ratio for each individual in the sample, not the ratio of the mean foot length and stature values for the sampled population. However, such data could not be extracted from Campbell et al. (1936). Moreover, Fessler et al. (2005) showed that the mean of the ratios differs from the ratio of the means by only $0.01 \%$ for data sets with fewer subjects than the study of Campbell et al. (1936).
} 
The approximate speeds that the people making the trackways were traveling were calculated using a regression equation derived from measurements by Cavanagh and Kram (1989) for a sample of twelve male recreational distance runners: velocity $=$ stride length $x 1.670-0.645$. Estimates of velocity derived from this equation should clearly be interpreted cautiously, as stride lengths at a given speed will be modified by variables such as leg length and body mass.

Respective track speeds in the T1-4 group range from $\sim 12 \mathrm{~km} \mathrm{hr}^{-1}$ for $\mathrm{T} 1$ to $\sim 14 \mathrm{~km}$ $\mathrm{hr}^{-1}$ for T4 (Table 2). The fact that there is only slight variation in stride length suggests that the people who made trackways 1-4 were in mid-run and taking the same course from south to north (Fig. 3a). The person in T1 was trotting, with a shorter stride than the others, two of whom were shorter in stature. It is difficult to know if these tracks are contemporary, but the close spacing between the trackways, along with their uniform orientation and similarity in appearance, suggests that they may have been made during the same event.

The direction of $\mathrm{T} 5$ and $\mathrm{T} 8$ shows that these individuals were headed towards a convergence point with the T1-4 individuals, suggesting that they may also have been contemporary and engaged in the same activity. Footprints from T8, which is higher up the depression rim, are not as deep as the others, indicating a slightly drier surface nearer the edge. Trackway 5 is the shortest with only four prints, restricting stride length to a single measurement. Foot length $(270 \mathrm{~mm})$ indicates that the person was $1.78 \pm$ $0.14 \mathrm{~m}$ tall. This individual was running at around $17 \mathrm{~km} \mathrm{hr}^{-1}$.

The most impressive track in terms of speed is T8. These footprints are $295 \mathrm{~mm}$ long and $100 \mathrm{~mm}$ wide; the estimated height of the person who made the tracks is $1.94 \pm$ $0.15 \mathrm{~m}(\sim 6.4 \mathrm{ft})$, close to that of the $\mathrm{T} 1$ individual. The tracks indicate that this individual was running the fastest of any person at the site. Pace length increases from 1.8 to $1.9 \mathrm{~m}$ over $11 \mathrm{~m}$, indicating acceleration, and speed is estimated at $\sim 20 \mathrm{~km} \mathrm{hr}^{-1}$. The surface on which this person was running was drying mud that left detailed impressions of foot architecture, with mud oozing between the toes, and slight heal slippage on the surface.

Average stride length in T6 is $1.17 \mathrm{~m}$, indicating a walking speed of $\sim 5 \mathrm{~km} \mathrm{hr}^{-1}$. The 205 -mm-long footprints suggest that this person was $1.35 \pm 0.10 \mathrm{~m}$ tall and probably an adolescent. The individual was walking at right angles to the main tracks and moving up slope. The seventh track contains the second smallest prints at the site at $160 \mathrm{~mm}$ in length, indicating a person smaller than the T6 individual $(1.05 \pm 0.08 \mathrm{~m})$ and probably a child. The track curves slightly to the right, and, in five paces, stride length decreases from 1.29 to $0.93 \mathrm{~m}$, showing a reduction in speed from $\sim 5$ to $3 \mathrm{~km} \mathrm{hr}^{-1}$.

\section{Implications and conclusions}

The size of the prints and the pace lengths in most trackways indicate tall individuals who were able to achieve high running speeds. There are at least two particularly tall people in the group, suggesting adult males in keeping with skeletal remains previously studied from the region, and Lake Garnpung in particular (Webb, 1989; Johnston et al., 2003; S. Webb, unpublished data). Such remains typically display a robust set of 
characteristics, including thick cranial vaults and long bone cortices, large jaws and brow ridges, heavy facial buttressing, and prominent sub-occipital and facial areas of muscle attachment.

Recent excavation and examination of two robust individuals on the Lake Garnpung shoreline $-6 \mathrm{~km}$ south of, and contemporary with, the footprint sited - showed these males to be 1.79 and $1.73 \mathrm{~m}$ tall (Johnston et al., 2003; S. Webb, unpublished data). An accompanying female was around $1.63 \mathrm{~m}$ in height. The upper height estimate of the robust Willandra Lakes Hominid 50, also discovered in the Lake Garnpung hinterland, about $10 \mathrm{~km}$ south of the footprint site, has been placed at around $1.77 \mathrm{~m}$ (Webb, 1989), similar to the T2 and T4 individuals. Foot size, pace length, and probable stature of the individuals at the footprint site are consistent with the robust people known to have inhabited the Willandra Lakes and other parts of southeastern Australia during the LGM (Stone and Cupper, 2003; S. Webb, unpublished data).

The presence of footprints from so many individuals representing all sizes and ages is a clear indicator of the collective activities of adults, adolescents, and children at the site. Although the larger lakes must have been especially attractive for fishing and the harvesting of shellfish, smaller ephemeral water sources in the nearby hinterlands were probably important for other activities, particularly the hunting of water birds and a variety of terrestrial game. They may also have offered more sheltered occupation areas for late Pleistocene populations than the exposed, glacial-age shorelines.

The footprint site widens our perceptions of a past society more graphically than other forms of archaeological study. It also presents an added dimension to our understanding of the morphology and physical capabilities of Pleistocene humans that is not implicit in osteological studies. Some of the recorded marks may be impressions of implements carried by these people, with the potential to reveal more about their technology and material culture. The footprints are a rare glimpse into life at the height of the last glacial period.

\section{Acknowledgements}

We thank the elders of the Barkindji, Mutthi Mutthi, and Ngiyampaa tribal groups of the Willandra Lakes World Heritage Area for their support. In particular, we thank Mary Pappin Jr., who discovered the first footprints during a site survey in August 2003. Michael Westaway of the Australian Department of Environment and Heritage and Harvey Johnston of the NSW Department of Environment and Conservation provided support and facilities. Jim Bowler and two anonymous referees made valuable comment on drafts of this manuscript. We dedicate this research to the memory of Peter Clark, a pioneer of archaeological and paleoenvironmental research in the Willandra Lakes, who died 1 July 2004. 


\section{References}

Adamiec, G., Aitken, M.J., 1998. Dose-rate conversion factors: update. Anc.. TL 16, $37-50$.

Adcock, G.J., Dennis, E.S., Easteal, S., Huttley, G.A., Jermiin, L.S.,

Peacock, W.J., Thorne, A., 2001. Mitochondrial DNA sequences in ancient Australians: implications for modern human origins. Proc. Natl. Acad. Sci. 98, 537-542.

Aitken, M.J., 1998. An Introduction to Optical Dating. Oxford University Press, Oxford.

Barker, S.L., Scheuer, J.L., 1998. Predictive value of human footprints in a forensic context. Med. Sci. Law 38, 341-346.

Behrensmeyer, A.K., Laporte, L.F., 1981. Footprints of a Pleistocene hominid in northern Kenya. Nature 289, 167-169.

Bowler, J.M., 1986. Spatial variability and hydrologic evolution of Australian lake basins: analogue for Pleistocene hydrologic change and evaporate formation. Palaeogeogr. Palaeoclimatol. Palaeoecol. 54, 21-41.

Bowler, J.M., 1998. Willandra Lakes revisited: environmental framework for human occupation. Archaeol. Oceania 33, 120-155.

Bowler, J.M., Johnston, H., Olley, J.M., Prescott, J.R., Roberts, R.G., Shawcross, W., Spooner, N.A., 2003. New ages for human occupation and climatic change at Lake Mungo, Australia. Nature 421, 837-840.

Campbell, T.D., Gray, J.H., Hackett, C.J., 1936. Physical anthropology of the Aborigines of central Australia. Oceania 7, 106-139.

Cavanagh, P.R., Kram, R., 1989. Stride length in distance running: velocity, body dimensions and added mass effects. Med. Sci. Sports Exerc. 21, 467-479.

Charteris, J., Wall, J.C., Nottrodt, J.W., 1981. Functional reconstruction of gait from the Pliocene hominid footprints at Laetoli, northern Tanzania. Nature 290, 496-498.

Cooper, A., Rambaut, A., Macaulay, V., Willerslev, E., Hansen, A.J., Stringer, C., 2001. Human origins and ancient human DNA. Science 292, 1655-1656.

Cupper, M.L., 2005. Last glacial to Holocene evolution of semi-arid rangelands in southeastern Australia. Holocene 15, 541-553.

Day, M.H., Wickens, E.H., 1980. Laetoli Pliocene hominid footprints and bipedalism. Nature 286, 385-387.

Deacon, H.J., 1966. The dating of the Nahoon footprints. S. Afr. J. Sci. 62, 111-113.

Facorellis, Y., Kyparissi, N., Maniatis, Y., 2001. The cave of Theopetra, Kalambaka: radiocarbon evidence for 50,000 years of human presence. Radiocarbon 43, 10291048 .

Fessler, D.M.T., Haley, K.J., Lal, R.D., 2005. Sexual dimorphism in foot length proportionate to stature. Ann. Hum. Biol. 32, 44-59.

Galbraith, R.F., Roberts, R.G., Laslett, G.M., Yoshida, H., Olley, J.M., 1999. Optical dating of single and multiple grains of quartz from Jinmium rock shelter, northern 
Australia: part I, experimental design and statistical models. Archaeometry 41, 339364.

Giles, E., Vallandigham, P.H., 1991. Height estimation from foot and shoeprint length. J. Forensic Sci. 36, 1134-1151.

Hay, R.L., Leakey, M.D., 1982. The fossil footprints of Laetoli. Sci. Am. 246, 38-45.

Hesse, P.P., Magee, J.W., van der Kaars, S., 2004. Late Quaternary climates of the Australian arid zone: a review. Quat. Int. 118-119, 87-102.

Hrdlicka, A., 1935. The Pueblos. Am. J. Phys. Anthropol. 20, 235-460.

Huntley, D.J., Godfrey-Smith, D.I., Thewalt, M.L.W., 1985. Optical dating of sediments. Nature 313, 105-107.

Johnston, H., Webb, S., Williams, D., 2003. Late Pleistocene burials from Lake Garnpung, Willandra Lakes Region World Heritage Area. In: Fairbairn, A. (Ed.), Colder and Drier for Longer. Australian Archaeological Association Conference Jindabyne, 4e7 December 2003. Centre for Archaeological Research, Australian National University, Canberra, p. 17.

Leakey, M.D., Hay, R.L., 1979. Pliocene footprints in the Laetolil Beds at Laetoli, northern Tanzania. Nature 278, 317-323.

Mejdahl, V., 1979. Thermoluminescence dating: beta-dose attenuation in quartz grains. Archaeometry 21, 61-72.

Mietto, P., Avanzini, M., Rolandi, G., 2003. Human footprints in Pleistocene volcanic ash. Nature 422, 133.

Mountain, E.D., 1966. Footprints in calcareous sandstone at Nahoon Point. S. Afr. J. Sci. 62, 103-111.

Murray, A.S., Roberts, R.G., 1997. Determining the burial time of single grains of quartz using optically stimulated luminescence. Earth Planet. Sci. Lett. 152, 163-180.

Murray, A.S., Wintle, A.G., 2000. Luminescence dating of quartz using an improved single-aliquot regenerative-dose protocol. Radiat. Meas. 32, 57-73.

Prescott, J.R., Hutton, J.T., 1994. Cosmic ray contributions to dose rates for luminescence and ESR dating: large depths and long-term time variations. Radiat. Meas. 23, 497-500.

Robbins, L.M., 1986. Estimating height and weight from size of footprints. J. Forensic Sci. 31, 143-152.

Roberts, D., Berger, L.R., 1997. Last Interglacial (c. 117 kyr) human footprints from South Africa. S. Afr. J. Sci. 93, 349-350.

Roberts, R.G., Jones, R., Smith, M.A., 1990. Thermoluminescence dating of a 50,000 year old human occupation site in northern Australia. Nature 345, 153-156.

Roberts, R.G., Jones, R., Spooner, N.A., Head, M.J., Murray, A.S., Smith, M.A., 1994. The human colonization of Australia: optical dates of 53,000 and 60,000 bracket human arrival at Deaf Adder Gorge, Northern Territory. Quat. Sci. Rev. 13, 575-583.

Stone, T.N., Cupper, M.L., 2003. Last Glacial Maximum ages for robust humans at Kow Swamp, southern Australia. J. Hum. Evol. 45, 99-111. 
Thorne, A., Grün, R., Mortimer, G., Simpson, J.J., McCulloch, M., Taylor, L., Curnoe, D., 1999. Australia's oldest human remains: age of the Lake Mungo 3 skeleton. J. Hum. Evol. 36, 591-612.

Topinard, P., 1878. Anthropology. Chapman and Hall, London.

Turney, C.S.M., Bird, M.I., Fifield, L.K., Roberts, R.G., Smith, M., Dortch, C.E., Gru"n, R., Lawson, E., Ayliffe, L.K., Miller, G.H., Dortch, J., Cresswell, R.G., 2001. Early human occupation at Devil's Lair, southwestern Australia, 50,000 years ago. Quat. Res. 55, 3-13.

Webb, S.G., 1989. The Willandra Lakes Hominids. Department of Prehistory, Research School of Pacific Studies, Australian National University, Canberra.

Wunderlich, R.E., Cavanagh, P.R., 2001. Gender differences in adult foot shape: implications for shoe design. Med. Sci. Sports Exerc. 33, 605-611.

Zhang, D.D., Li, S.H., 2002. Optical dating of Tibetan human hand- and footprints: an implication for the palaeoenvironment of the last glaciation of the Tibetan Plateau. Geophys. Res. Lett. 29, 1072-1074. 
Table 1: Footprint measurements:

\begin{tabular}{|c|c|c|c|c|c|}
\hline $\begin{array}{l}\text { Footprint/ } \\
\text { track }\end{array}$ & $\begin{array}{l}\text { Footprint length } \\
\text { (maximum, } \\
\text { in } \mathrm{mm} \text { ) }\end{array}$ & $\begin{array}{l}\text { Footprint width } \\
\text { (maximum, } \\
\text { in } \mathrm{mm} \text { ) }\end{array}$ & $\begin{array}{l}\text { Left (L) } \\
\text { or right } \\
\text { (R) foot }\end{array}$ & $\begin{array}{c}\text { Direction } \\
\left({ }^{\circ}\right)\end{array}$ & $\begin{array}{c}\text { Estimated } \\
\text { stature }(\mathrm{m})^{\mathrm{a}}\end{array}$ \\
\hline 1 & 270 & 90 & $\mathrm{R}$ & 44 & $1.78 \pm 0.13$ \\
\hline 2 & 250 & 85 & $\mathrm{~L}$ & 155 & $1.65 \pm 0.12$ \\
\hline 3 & 190 & 75 & $\mathrm{~L}$ & 22 & $1.25 \pm 0.09$ \\
\hline 4 & 190 & na & $\mathrm{R}$ & 95 & $1.25 \pm 0.09$ \\
\hline 5 & 260 & na & $\mathrm{R}$ & 26 & $1.71 \pm 0.13$ \\
\hline 6 & 220 & na & $\mathrm{L}$ & 180 & $1.45 \pm 0.11$ \\
\hline 7 & 180 & na & $\mathrm{R}$ & 250 & $1.19 \pm 0.09$ \\
\hline 8 & 200 & 70 & $\mathrm{R}$ & 21 & $1.32 \pm 0.10$ \\
\hline 9 & 205 & 65 & $\mathrm{~L}$ & 341 & $1.35 \pm 0.10$ \\
\hline 10 & 200 & na & $\mathrm{R}$ & 95 & $1.32 \pm 0.10$ \\
\hline 11 & 265 & 80 & $\mathrm{R}$ & 7 & $1.75 \pm 0.13$ \\
\hline 12 & 250 & 85 & $\mathrm{R}$ & 27 & $1.65 \pm 0.12$ \\
\hline 13 & 230 & 80 & $\mathrm{R}$ & 255 & $1.51 \pm 0.11$ \\
\hline 14 & 260 & na & $\mathrm{R}$ & 350 & $1.71 \pm 0.13$ \\
\hline 15 & 205 & 75 & $\mathrm{R}$ & 226 & $1.35 \pm 0.10$ \\
\hline 16 & na & 90 & $\mathrm{R}$ & 37 & na \\
\hline 17 & 265 & 85 & $\mathrm{~L}$ & 0 & $1.75 \pm 0.13$ \\
\hline 18 & 260 & 80 & $\mathrm{~L}$ & 0 & $1.71 \pm 0.13$ \\
\hline 19 & na & 95 & $\mathrm{R}$ & 180 & na \\
\hline 20 & 285 & 90 & $\mathrm{R}$ & 300 & $1.88 \pm 0.14$ \\
\hline 21 & 230 & na & na & 200 & $1.51 \pm 0.11$ \\
\hline 22 & 275 & 95 & $\mathrm{R}$ & 5 & $1.81 \pm 0.14$ \\
\hline 23 & 280 & 95 & $\mathrm{R}$ & 15 & $1.84 \pm 0.14$ \\
\hline 24 & 290 & 100 & $\mathrm{~L}$ & 50 & $1.91 \pm 0.14$ \\
\hline 25 & 220 & na & $\mathrm{L}$ & 35 & $1.45 \pm 0.11$ \\
\hline 26 & 290 & na & na & 10 & $1.91 \pm 0.14$ \\
\hline 27 & 260 & 85 & $\mathrm{R}$ & 56 & $1.71 \pm 0.13$ \\
\hline 28 & 220 & 80 & $\mathrm{R}$ & 24 & $1.45 \pm 0.11$ \\
\hline 29 & 285 & 85 & $\mathrm{~L}$ & 75 & $1.88 \pm 0.14$ \\
\hline 30 & 240 & 80 & $\mathrm{R}$ & 75 & $1.58 \pm 0.12$ \\
\hline 31 & 130 & 50 & $\mathrm{R}$ & 105 & $0.86 \pm 0.06$ \\
\hline 32 & 200 & 75 & $\mathrm{R}$ & 120 & $1.32 \pm 0.10$ \\
\hline 33 & 200 & 70 & $\mathrm{~L}$ & 90 & $1.32 \pm 0.10$ \\
\hline 34 & 190 & 65 & $\mathrm{~L}$ & 90 & $1.25 \pm 0.09$ \\
\hline 35 & 180 & 70 & $\mathrm{R}$ & 110 & $1.19 \pm 0.09$ \\
\hline 36 & 180 & 75 & $\mathrm{~L}$ & 80 & $1.19 \pm 0.09$ \\
\hline 37 & 200 & 70 & $\mathrm{R}$ & 63 & $1.32 \pm 0.10$ \\
\hline 38 & 220 & 85 & $\mathrm{~L}$ & 90 & $1.45 \pm 0.11$ \\
\hline 39 & 280 & 90 & $\mathrm{~L}$ & 25 & $1.84 \pm 0.14$ \\
\hline 40 & 210 & na & $\mathrm{L}$ & 100 & $1.38 \pm 0.10$ \\
\hline 41 & 240 & 75 & $\mathrm{R}$ & 183 & $1.58 \pm 0.12$ \\
\hline 42 & na & 80 & $\mathrm{R}$ & 70 & na \\
\hline 43 & 190 & 65 & $\mathrm{~L}$ & 199 & $1.25 \pm 0.09$ \\
\hline 44 & 255 & 85 & $\mathrm{~L}$ & 20 & $1.68 \pm 0.13$ \\
\hline 45 & 250 & 85 & $\mathrm{R}$ & 120 & $1.65 \pm 0.12$ \\
\hline 46 & 265 & 85 & $\mathrm{~L}$ & 24 & $1.75 \pm 0.13$ \\
\hline 47 & 244 & 80 & $\mathrm{~L}$ & 182 & $1.61 \pm 0.12$ \\
\hline 48 & 235 & 70 & R & 235 & $1.55 \pm 0.12$ \\
\hline T1 & 300 & 100 & $\mathrm{~L}$ and $\mathrm{R}$ & 30 & $1.98 \pm 0.15$ \\
\hline $\mathrm{T} 2$ & 270 & 95 & $\mathrm{~L}$ and $\mathrm{R}$ & 20 & $1.78 \pm 0.13$ \\
\hline T3 & 285 & 95 & $\mathrm{~L}$ and $\mathrm{R}$ & 20 & $1.88 \pm 0.14$ \\
\hline $\mathrm{T} 4$ & 270 & 95 & R & 15 & $1.78 \pm 0.13$ \\
\hline T5 & 275 & 90 & $\mathrm{~L}$ and $\mathrm{R}$ & 34 & $1.81 \pm 0.14$ \\
\hline T6 & 205 & 70 & $\mathrm{~L}$ and $\mathrm{R}$ & 290 & $1.35 \pm 0.10$ \\
\hline $\mathrm{T} 7$ & 160 & 70 & $\mathrm{~L}$ and $\mathrm{R}$ & 342 & $1.05 \pm 0.08$ \\
\hline T8 & 295 & 100 & $\mathrm{~L}$ and $\mathrm{R}$ & 28 & $1.94 \pm 0.15$ \\
\hline
\end{tabular}

${ }^{\mathrm{a}}$ Height $=$ foot length $\times 6.585 \pm 0.495$. 
Table 2: Metrical characteristics of footprints and trackways.

\begin{tabular}{lcccccc}
\hline Track & $\begin{array}{c}\text { Number } \\
\text { of prints }\end{array}$ & $\begin{array}{c}\text { Track } \\
\text { length (m) }\end{array}$ & $\begin{array}{c}\text { Footprint } \\
\text { length } \\
\text { (maximum, } \\
\text { in mm) }\end{array}$ & $\begin{array}{c}\text { Estimated }_{\text {stature }^{\mathrm{a}}(\mathrm{m})} \\
\text { length }(\mathrm{m})\end{array}$ & $\begin{array}{c}\text { Stride } \\
\text { lestimated } \\
\text { speed }^{\mathrm{b}} \\
\left(\mathrm{km} \mathrm{hr}^{-1}\right)\end{array}$ \\
\hline T1 & 14 & 15.3 & 300 & $1.98 \pm 0.15$ & $2.33 \pm 0.04$ & 12 \\
T2 & 13 & 15.3 & 270 & $1.78 \pm 0.13$ & $2.52 \pm 0.05$ & 13 \\
T3 & 11 & 13.8 & 285 & $1.88 \pm 0.14$ & $2.69 \pm 0.03$ & 14 \\
T4 & 15 & 19.5 & 270 & $1.78 \pm 0.13$ & $2.75 \pm 0.20$ & 14 \\
T5 & 4 & 5.2 & 275 & $1.81 \pm 0.14$ & $3.23 \pm \mathrm{na}$ & 17 \\
T6 & 5 & 2.6 & 205 & $1.35 \pm 0.10$ & $1.17 \pm 0.10$ & 5 \\
T7 & 7 & 3.6 & 160 & $1.05 \pm 0.08$ & $1.29 \pm 0.01$ & 5 \\
& 7 & 13.0 & 295 & $1.94 \pm 0.15$ & $3.71 \pm 0.08$ & 20 \\
T8 & 7 & & & & $0.93 \pm \mathrm{na}^{\mathrm{c}}$ & 3 \\
\hline
\end{tabular}

${ }^{\text {a }}$ Height $=$ foot length $\times 6.585 \pm 0.495$.

b Velocity $=$ stride length $\times 1.670-0.645$ (Cavanagh and Kram, 1989).

c Speed change in track as person slows.

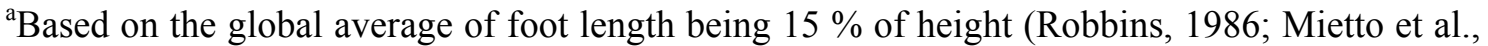
2003). ' Speed was estimated using a transposition of the formula: Speed $=\sqrt{ }($ stride length/leg length $\mathrm{x}$ gravitational acceleration) $\mathrm{x}$ 'dimensionless speed' (Alexander, 1989). 'Speed change in track as person slows. 
Table 3: Summary Optical Age Data

\begin{tabular}{|c|c|c|c|c|c|c|c|c|c|c|c|c|}
\hline Sample & $\begin{array}{c}\text { Depth }^{\mathrm{a}} \\
\text { (m) }\end{array}$ & $\begin{array}{c}\text { Water } \\
\text { (\%) }\end{array}$ & $\begin{array}{l}\mathbf{K}^{\mathbf{b}} \\
(\%)\end{array}$ & $\begin{array}{c}\mathbf{T h}^{\mathrm{b}} \\
(\mathbf{p p m})\end{array}$ & $\begin{array}{c}\mathbf{U}^{\mathbf{b}} \\
(\mathbf{p p m})\end{array}$ & $\begin{array}{c}\alpha \text { radiation } \\
\left(\mathbf{G y ~ k a}^{-1}\right)\end{array}$ & $\begin{array}{c}\beta \text { radiation } \\
\left(\mathrm{Gy} \mathrm{ka}^{-1}\right)\end{array}$ & $\begin{array}{c}\gamma \text { radiation } \\
\left(\mathbf{G y ~ k \mathbf { k a } ^ { - 1 } )}\right.\end{array}$ & 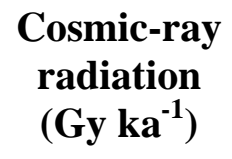 & $\begin{array}{l}\text { Total dose } \\
\text { rate } \\
\left(\mathrm{Gy} \mathrm{ka}^{-1}\right)\end{array}$ & $\begin{array}{c}\text { Equivalent } \\
\text { dose }^{c} \\
\text { (Gy) }\end{array}$ & $\begin{array}{l}\text { Optical } \\
\text { age (ka) }\end{array}$ \\
\hline GP02 & 1.10 & $5.0 \pm 1.0$ & $0.50 \pm 0.01$ & $2.54 \pm 0.02$ & $0.53 \pm 0.02$ & $0.03 \pm 0.01$ & $0.47 \pm 0.02$ & $0.36 \pm 0.03$ & $0.17 \pm 0.02$ & $1.03 \pm 0.04$ & $19.9 \pm 0.8$ & $19.4 \pm 1.1$ \\
\hline GP03 & 0.65 & $5.0 \pm 1.0$ & $0.42 \pm 0.01$ & $2.59 \pm 0.02$ & $0.48 \pm 0.02$ & $0.03 \pm 0.01$ & $0.41 \pm 0.02$ & $0.25 \pm 0.02$ & $0.16 \pm 0.02$ & $0.85 \pm 0.03$ & $19.6 \pm 0.7$ & $23.0 \pm 1.2$ \\
\hline GP04 & 0.07 & $5.0 \pm 1.0$ & $0.42 \pm 0.01$ & $2.40 \pm 0.02$ & $0.56 \pm 0.02$ & $0.03 \pm 0.01$ & $0.42 \pm 0.02$ & $0.26 \pm 0.06$ & $0.17 \pm 0.02$ & $0.88 \pm 0.08$ & $16.9 \pm 0.8$ & $19.2 \pm 1.9$ \\
\hline
\end{tabular}

${ }^{\mathrm{a}}$ Depths prior to recent erosion estimated to be $\sim 1.6,2.2$, and $1.6 \mathrm{~m}$ for GP02-4, respectively.

bobtained by INAA (Becquerel Laboratories, Menai).

${ }^{\mathrm{c}}$ Including a $\pm 2 \%$ systematic uncertainty associated with calibration of the laboratory beta-source. 
Fig. 1. a) Map showing the Willandra Lakes system in southeastern Australia.

Fig 1. b) Location of the footprint site between Lakes Garnpung and Leaghur.
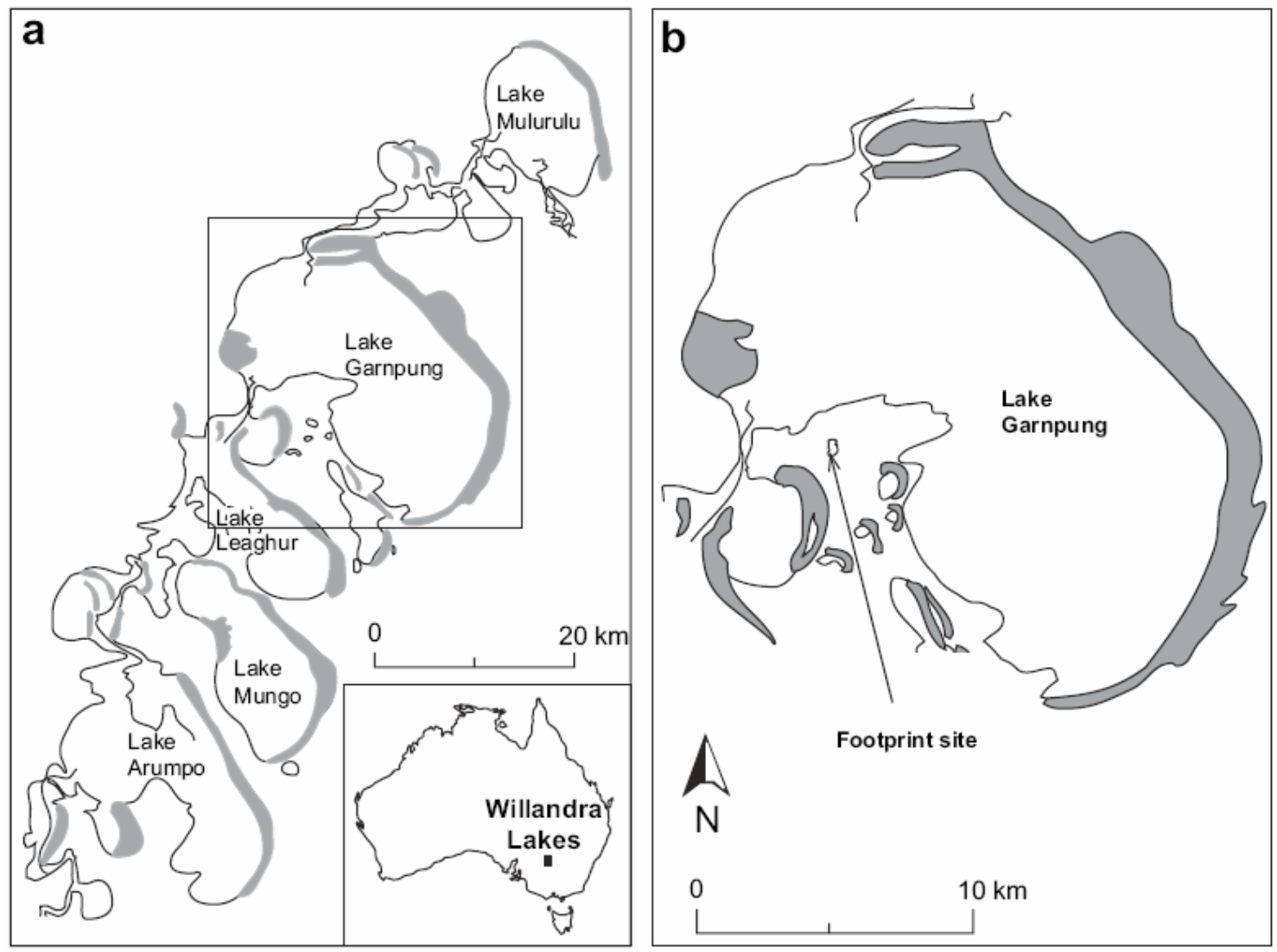
Fig. 2. a) Plan of the pavement showing the distribution of the footprints and orientation of the trackways (T1-8). The pavement is eroded along its northwestern margin and partially covered to the east by a thin sand sheet, grading into a $6 \mathrm{~m}$ high dune (stippled area). Test excavations showed that at least three footprints of T1 continue under the covering sand sheet. Optical ages in ka are shown.

Fig 2. b) Section $X-X^{\prime}$ across the pavement showing the stratigraphic relationships of the constraining sand units and their ages.
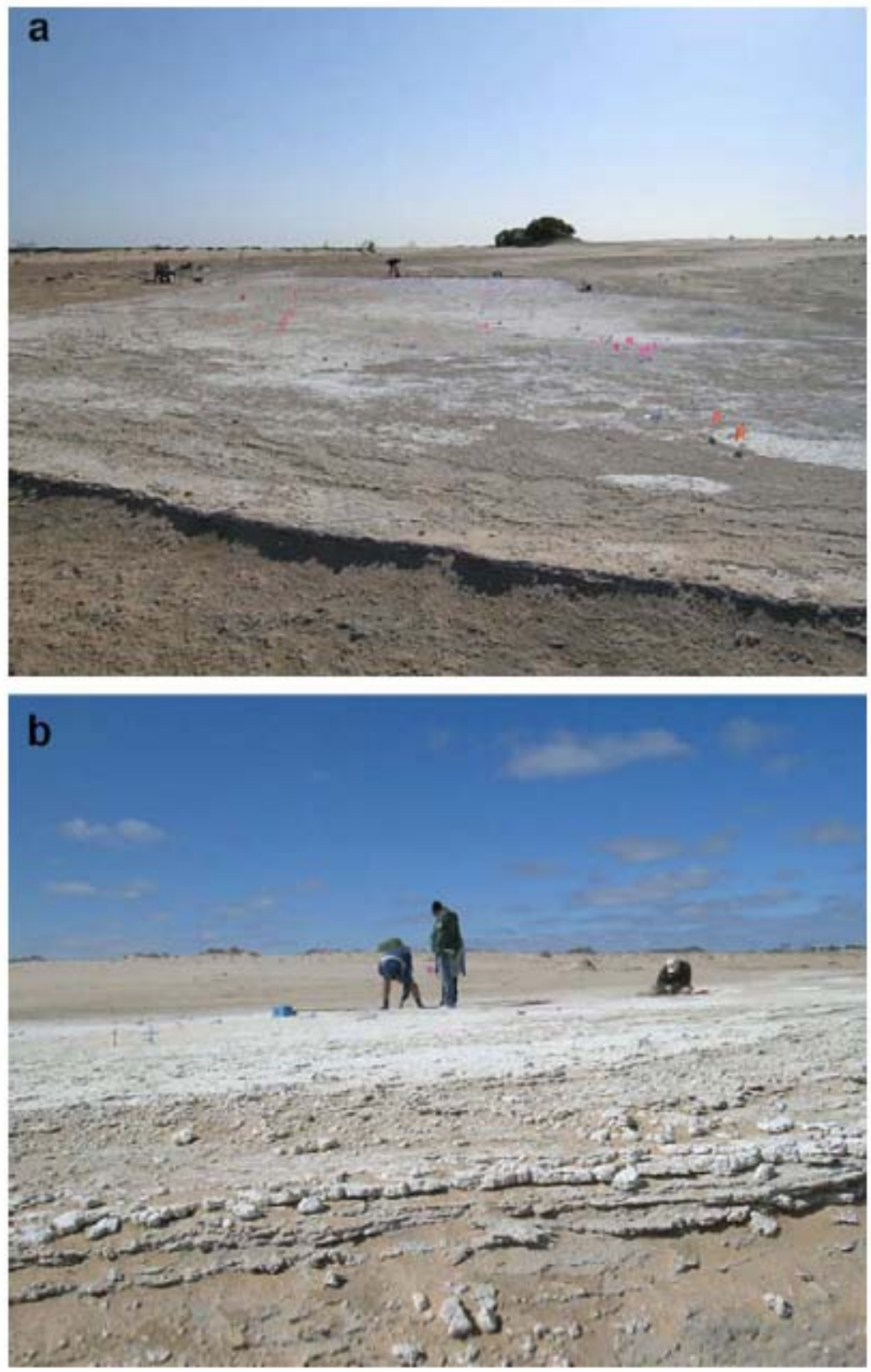

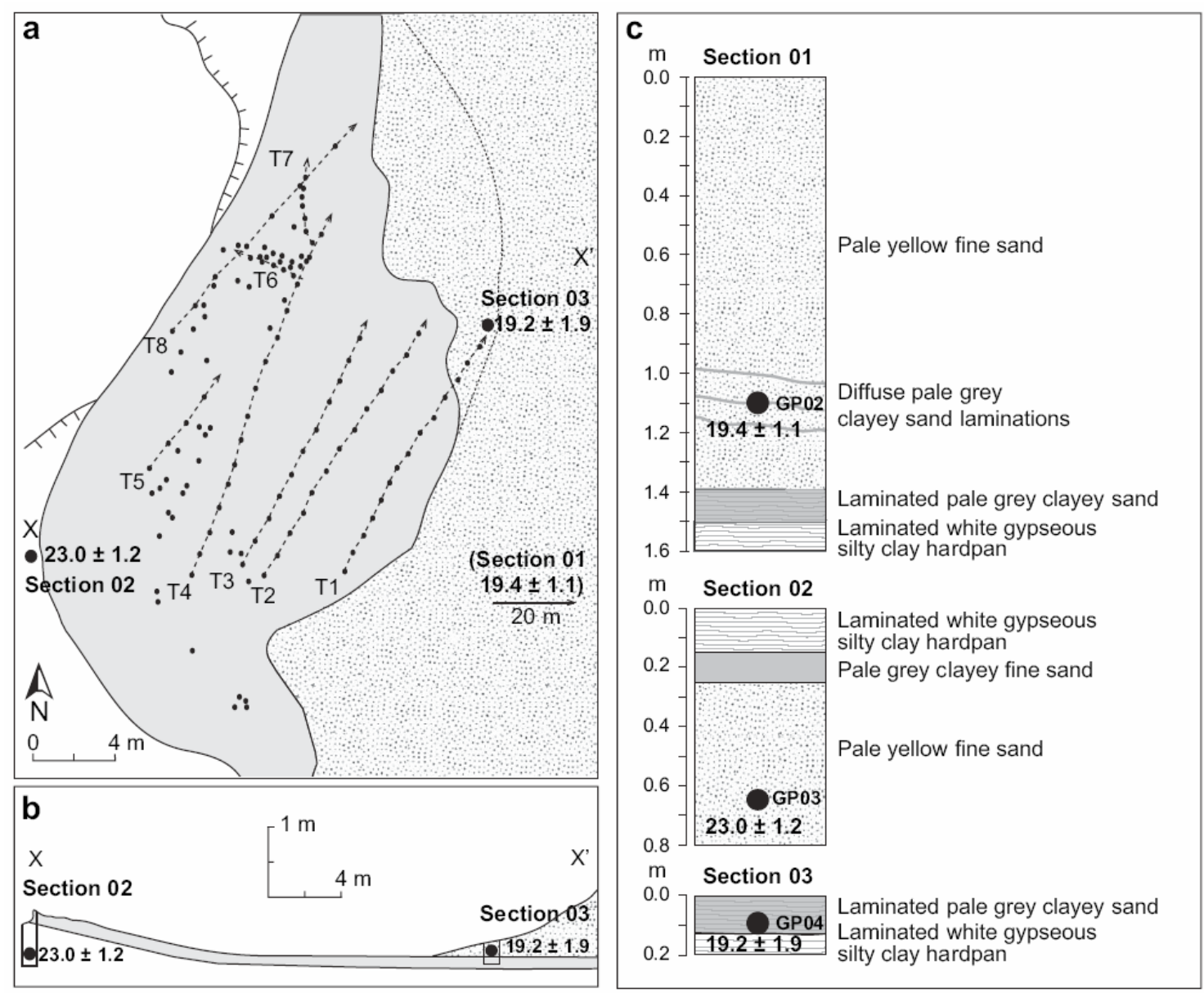

Fig. 3. a) Plan of the footprint site showing the distribution of the prints and orientation of the trackways (T1e8). The hardpan is eroded along its northwestern margin and partially covered to the east by a thin clayey sand sheet, grading into a 6-mhigh dune (stippled area). Test excavations showed that at least three footprints from T1 continue under the covering clayey sand sheet. Optical ages in ka are shown.

Fig 3. b) Section $X-X \#$ across the hardpan showing the stratigraphic relationships of the constraining clayey sand and sand units and their ages.

Fig 3 c) Stratigraphic sections through the sediments at the footprint site showing the relationship of the units and OSL sampling depths. 
Fig. 4. a). Track 4 footprints postulated to be those of a $\sim 178 \mathrm{~cm}$ tall male crossing the pavement (note that all the impressions are those of the right foot).

Fig. 4. b). Print from T1 showing detailed foot morphology including toe impressions.
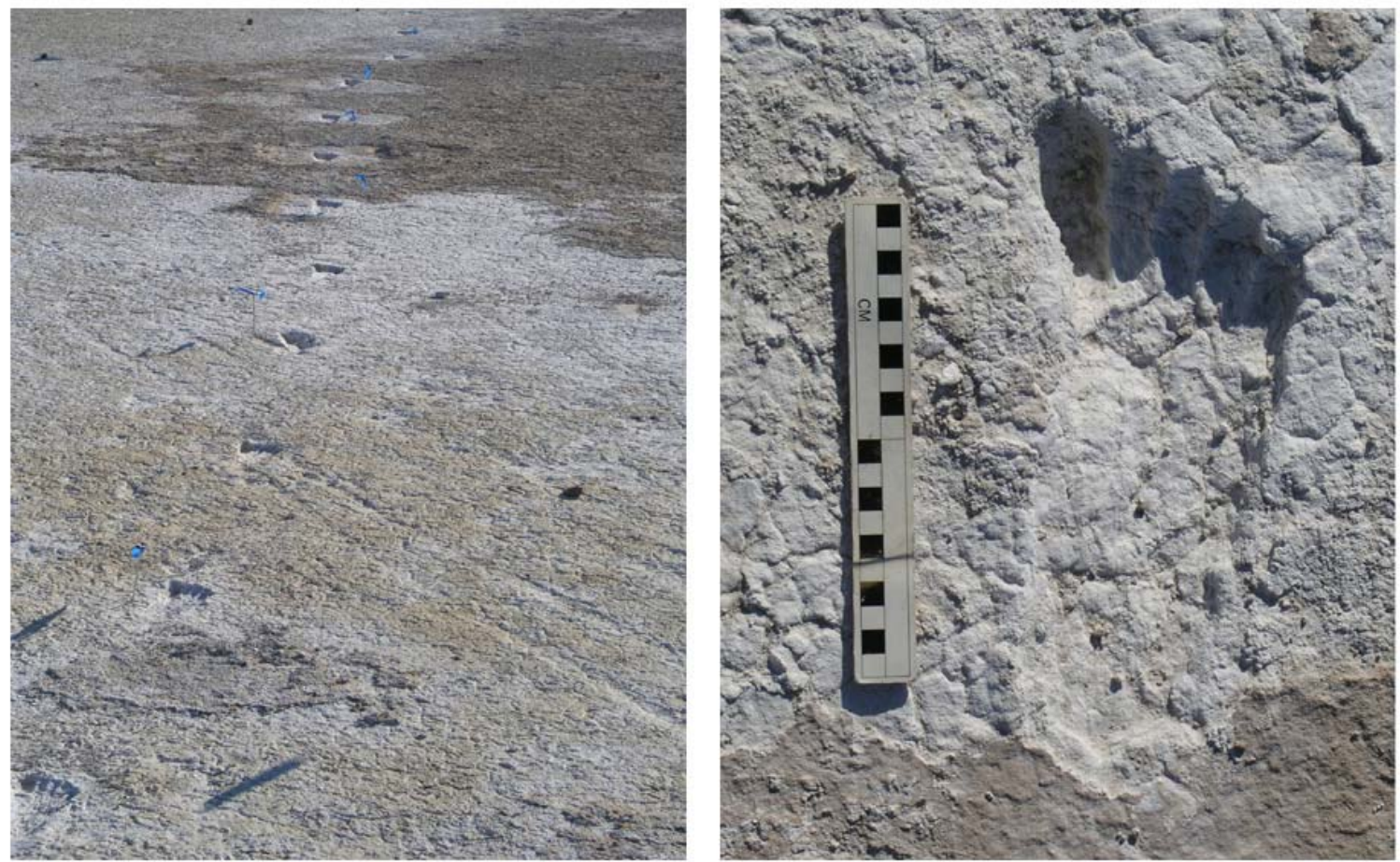

a

b
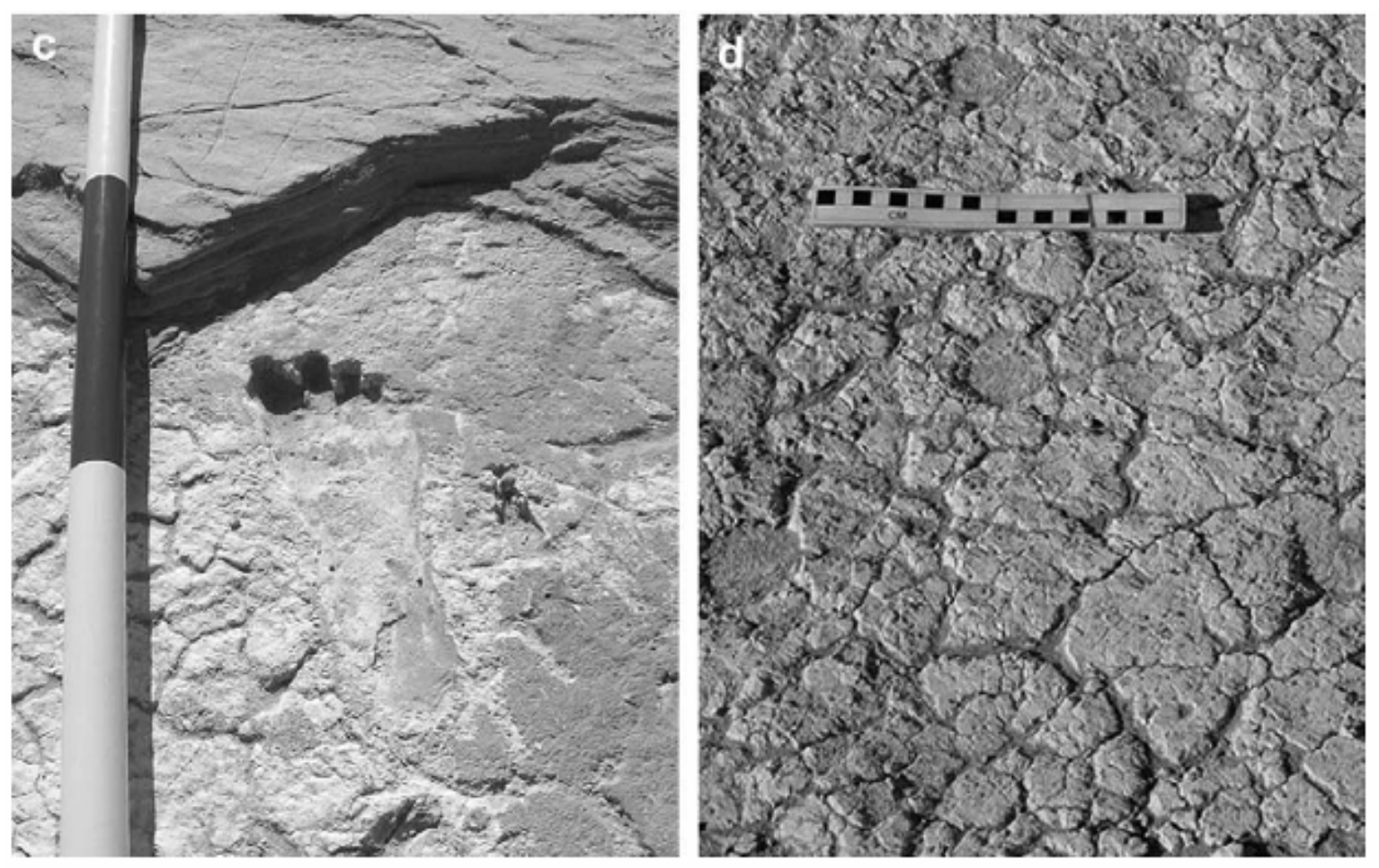

Fig. 4. c) Thin clayey sand sheet covering T1, dated by luminescence to $19.2 \_1.9 \mathrm{ka}$ (GP04).

Fig. 4. d ) Circular impressions on the second-highest lamination. 
Fig. 5. Orientation of footprints. Trackways 1-5 and 8 contain 64 of the prints pointing in a north-northeasterly direction.

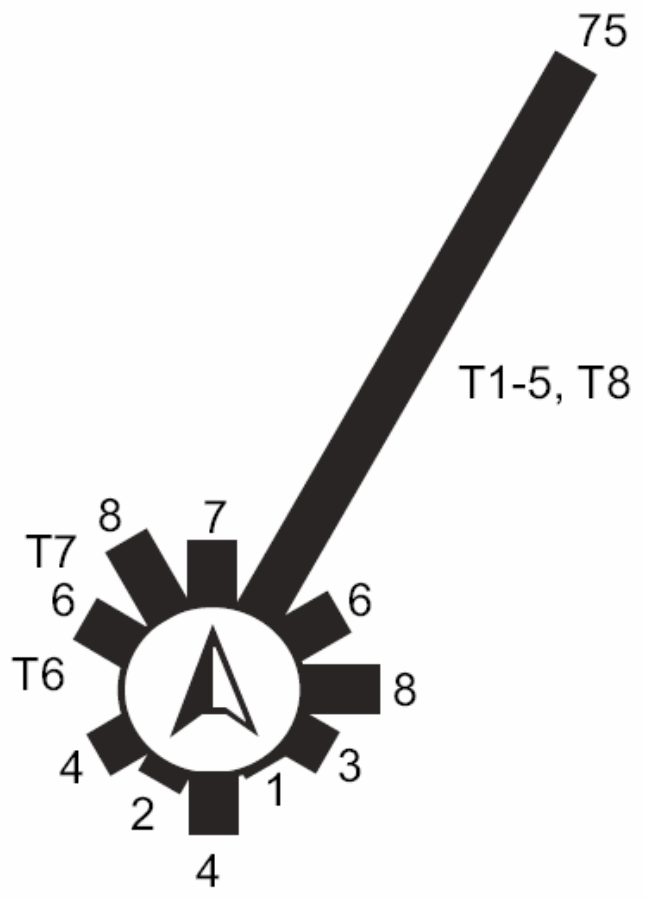

Fig. 6. Frequencies of different footprint lengths at the site. Footprints within each trackway are only included as a single value. A minimum of eight individuals are represented, assuming a $10 \mathrm{~mm}$ imprecision between footprint and actual foot lengths. Mean foot lengths with 1s confidence intervals are shown for different sex and age divisions of central Australian Aborigines (Campbell et al., 1936). Dashed error bars are estimates of variability based on that for the 11e17-year-old male sample. The numbers of individuals in each sample are shown in parentheses.

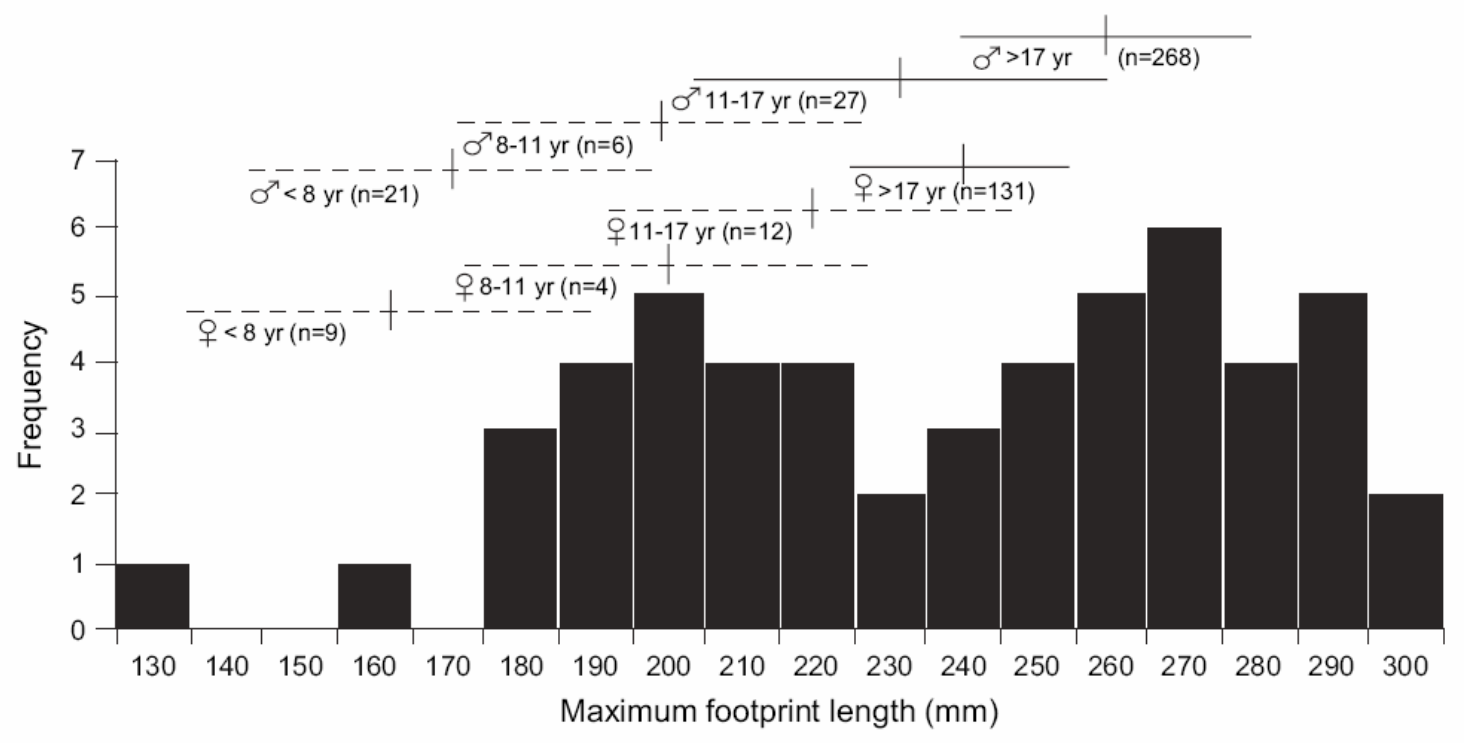

